\title{
ETHNIC AND RELIGIOUS DISPARITIES IN THE APUSENII SĂLAJULUI FROM COMMUNISM TO CAPITALISM
}

\author{
Mădălin-Sebastian LUNG * \\ Ph.D. Student, Babeș-Bolyai University, Doctoral School of Geography, Faculty of Geography, \\ Clinicilor Street, 5-7, 400006, Cluj-Napoca, România, e-mail: lungmadalin@yahoo.com
}

Citation: Lung, M.-S. (2021). Ethnic and Religious Disparities in the Apusenii Sălajului from Communism to Capitalism. Revista Română de Geografie Politică, 23(1), 10-21. https://doi.org/10.30892/rrgp.231102-345

\begin{abstract}
The aim of this study was to achieve an evolutionary-temporal analysis of demographic evolution, ethnic and confessional structure in Apusenii Sălajului. The period subjected to the study begins with the abdication of King Mihai I and the establishment of communism in Romania in the year 1948. The two demographic structures have undergone significant influences from the regime, contributing decisively to their modification. Unfortunately, the confessional structure had the most to suffer because of the atheism promoted by the communists. In Apusenii Sălajului there is an important confessional diversity due to several ethnicities that populate the mountain space. The most destructive confessional community in the Apusenii Sălajului was the Greek Catholic. In the year 1948, the regime banned this confession, with the population constrained to convert to the Orthodox confessional. Priests who did not obey, were arrested and convicted, many dying in prisons, as was the case of bishops. Because of these repression, the population passed to the Orthodox confession. All confessions were compelled to pass to the Orthodox cult, being the only cult accepted by the regime. Five censuses were used to carry out the study, from 1941, 1956, 1977, 1992 and 2011. The census of 1956 and 1977 are those of the Communist period that did not record the confession. Thus, in order to be able to analyze and observe the significant changes we used the data from the census in the year 1941.
\end{abstract}

Key words: disparities, ethnicity, confession, communism, capitalism

\section{INTRODUCTION}

The Apusenii Sălajului is the north-eastern part of the Apuseni Mountains (figure 1), with five administrative-territorial units in their composition (Cizer, Halmășd, Plopiș, Sâg, Valcău de Jos), comprising a total of 21 localities. It is the only subregion between the six of the Apuseni Mountains that owns no city, only rural administrative units (rural area). 
The five administrative units form a genuine traditional rural area where multiethnic and reliogious values have continuously strengthened under the influence of a diverse range of factors (socio-economic, historical-cultural, administrative-policy). These factors can be referred to as generational factors of risk, through which we can understand the essence of processes or phenomena, which contribute to the occurrence of one or another type of risk and which determines its character (Romanov and Butuhanov, 2001 quoted by Surd et al., 2007, p. 11).

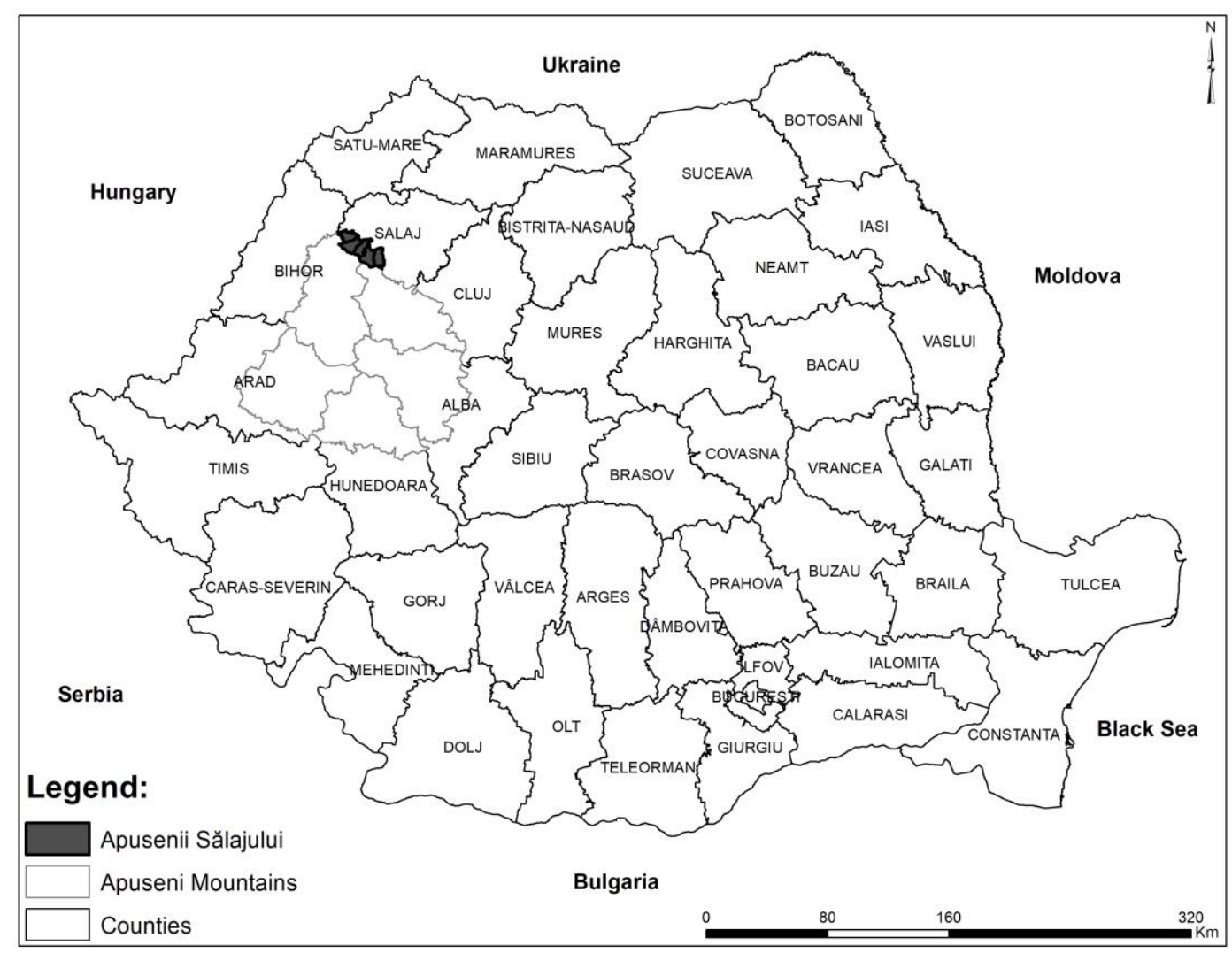

Figure 1. Geographic localization of the Apusenii Sălajului

Through this study we wanted to conduct an analysis of the demographic evolution in the Apusenii Sălajului, the only subregion of the Apuseni Mountains consisting entirely of rural space. However, the two main objectives focused on studying the ethnic and confessional structure. After the establishment of communism, there were important changes in the two structures of the Apusenii Sălajului. The confession was marginalised by the socialists, and the churches were outlawed, except for the Orthodox Church. The confessional and ethnic disparities were pronounced because in this part of the Apusenilor, there was an ethnical-confessional diversity. At one place lived, Romanians, Hungarians, Slovaks, Gypsy, these ethnicities belonging to several confessions such as: Orthodox, Greek Catholic, Roman Catholic, Reformed. The regime wished to form a single, Orthodox confession, to which the believers of the other religious denominations would be converted. In particular, the repressures were on the 
Roman Church, the priests and believers who were not obeunled were arrested and convicted. During the study we see that territorial disparities have been closely linked to the confessional and ethnic structure, favouring demographic decreases and migration of the population. Unfortunately, the dysfunctions produced in the period 1948-1989, retained continuity after the end of communism. Thus, at the census of the year 2011, the ethnic-confessional framework of the Apusenii Sălajului was radically changed.

The research of demographic evolution, but especially of the two structures, was the subject of analysis for researchers from both Romania and other countries (Clark, 2002; Kamusella, 2004; Mukharyamov, 2004; Akturk, 2007; Gumenai, 2008; Herman, 2009; Ghiță, 2011; Macháček, 2011; Truzzi and Bassanezi, 2013; Scarpim, 2014; Tofan, 2014; Majo, 2015; Matlovič et al., 2015; Shemshurenko et al., 2016; Simoni and Dagnino, 2016; Darulová et al., 2018; Zekanovic and Gnjato, 2018; Gostyusheva and Dolzhikov, 2019; Lung, 2019a, b; Ilieș et al., 2020; Lung and Mureșan, 2020). The studies were addressed from different perspectives, because both ethnicity and confession are an important support of human understanding and living. If the two structures are harmonising, then a geographic space can thrive continuously, reaching a high level of development. Also, merging the elements of the two demographic structures can lead to a multiculturality, capable of creating urban or rural development models. However, structures and multiculturality can be directly influenced by the political factor that can have positive or negative benefits, as was the case from the Apusenii Sălajului during the etatist period.

\section{DATA SOURCE AND METHODOLOGY}

For the drafting of this article, we used the statistical data from five population and housing censuses. The first census used was the year 1941, in order to see the major changes in the confessional structure. Unfortunately, the confession was not included in the census of 1956, nor in the year 1977, being the census of the communist period. For this reason we have chosen to use for confession the census of the year 1941 (Rotariu et al., 2002). The next useful new census was the one in the year 1956 (Central Statistical Directorate, 1961), which was also a first census of the population after the socialist regime was established in the country's leadership. The third, was the census of the year 1977 (Directorate-General for Statistics, 1980), which followed the Decree No. 770 of 1 October 1966 prohibiting the interruption of pregnancy. The fourth census used was the year 1992 (County Department of Statistics Sălaj, 1994), being the first demographic census after the end of communism, and the last useful new census was the one in 2011 (National Institute of Statistics, NIS).

In a first step the statistical data was introduced into the Microsoft Excel2013 program, where they were processed and then generated several tables. The data was then entered in the ArcMap 10.3 attribute table, with a series of maps with study-specific demographic indicators. Geographic Information Systems have also been used to generate a map of the geographical position of the mountainous region studied. In order to achieve the best possible timeline of the demographic aspects contained in the work, the great help was the specialty bibliography. Through it, we were able to extract interesting information on the evolution of ethnics and confessions in the region, from communism (ethatism) to capitalism (democracy). However, the information about confessions was quite restricted because of the atheistic policy of the communist regime. 


\section{RESULTS AND DISCUSSIONS}

A cycle of territorial disparities in the demographic component of the Apusenii Sălajului began with the abdication of King Mihai I and the establishment of the communist regime in Romania. The setting of the monarchy in Romania began on November 12, 1947, when the king and the mother Queen went to London to witness the marriage of Princess Elisabeth, Dej and Groza hoping that he would not return (Quinlan, 1977, p. 157). The king and his mother returned on December $21^{\text {st }}$, and nine days later the communists acted, calling on the king in Bucharest, where they presented his declaration of abdication. The refusal of the monarch to sign, was attacked by Groza by threatening the onset of the civil war, which put the king in the face of signing. The signing of abdication ended the Romanian monarchy, and on 30 December 1947 the People's Republic of Romanian was proclaimed. Communism lasted from 1948 to Revolution in the year 1989 (Deletant, 2001, p. 72).

The traditional countryside of the Apusenii Sălajului has contributed to the systematic intensification of demographic decline in the communist period, especially as a result of law No. 58/1974 referring to the systematization of the territory and localities. The imposition of conditions for spatial planning and the distribution of the built heritage has been negatively sighted on the population of the Apusenii Sălajului. Even though in the socialist period the decree on the prohibition of abortion was in force, through the law of systematization, the rural area of party entered a process of depopulation. This depopulation was the result produced by the law of systematization of localities, whereby rural localities were constrated to develop to the level of cities, or were to be destroyed. However, the demographic decreases recorded in the period 1956-1977 were not so significant because the law had only entered into force for three years in 1974. Its effects were felt in the period 1977-1992 when the values of population decreases were raised.

Table 1. Demographic evolution in the Apusenii Sălajului

(Source: own processing after population census of 21 February 1956: Population demographic Structure: number and territorial distribution of population, marital status, nationality, mother tongue, training level, families, Central Directorate of Statistics, Bucharest, 1961; Population and Housing census of 5 January 1977, Directorate-General for Statistics, Bucharest, 1980; Population census and inhabitants of 7 January 1992: Sălaj County: General results, County Department of Statistics Sălaj,

Zalău, 1994; Population and Housing Census of 2011, National Institute of Statistics, Bucharest)

\begin{tabular}{|c|c|c|c|c|c|c|c|}
\hline Years & 1956 & 1977 & $\%$ & 1992 & $\%$ & 2011 & $\%$ \\
\hline Number & 21.373 & 19.484 & -8.83 & 16.009 & -17.83 & 12.775 & -20.20 \\
\hline
\end{tabular}

The largest demographic decrease in the period 1956-1977 was recorded in the Sâg, which was $12.21 \%$, followed by Halmăşd by $10.13 \%$. From 1977 to the first capitalist census, the decline exploded, with the highest decrease rate of $27.99 \%$ in the Cizer. Three other territorial units recorded decreases between 10 and $20 \%$ (Plopiș 19.24\%, Halmășd 17.05\%, Sâg 14.68\%). The lowest rate of decrease was in the Valcău de Jos $(9.18 \%)$, but compative with the previous period the percentage value is almost double in 1992. The transitional period from communism to capitalism meant the continuity of the depopulation of the Apusenii Sălajului, so from 1992 to 2011, three units (Valcău de Jos 20.78\%, Plopiș 19.43\%, Halmășd $17.08 \%$ ) recorded higher demographic loss values than in the previous period. It should be noted that in the Cizer the decrease rate decreased greatly compared with 
the previous temporal gauge, from $27.99 \%$ to $19.80 \%$, and the Sâg decreased slightly more sensitive from $14.68 \%$ to $13.83 \%$ (table 1 ).

These demographic losses are closely linked to the evolution of the ethnic structure and the confessional structure.

\section{Changes in the ethnic structure of administrative-territorial units in the Apusenii Sălajului}

The $12.21 \%$ decrease in the Cizer between 1956-1977 was due to the numerical decline of ethnic Romanians by $11.63 \%$. Similar situation was in Halmăşd, where the flock of Romanians decreased by $14.29 \%$, and the slovaks with 35.60\%. The largest Slovak community in the Apusenii Sălajului was positioned in the administrative territory of Plopiss. The share of the Slovak community in the ethnic structure of the commune was $32 \%$ and Romanians of $68 \%$. However, during this period both ethnicities suffered losses, with the Romanian community losing $9.58 \%$ of the actual, and the Slovak community $10.73 \%$. At the level of the villages of the Plopiş territorial unit, $90.79 \%$ of Slovak citizens were inhabitants of the village of Făgetu, forming a well-rooted Slovak demographic pole in the space of the Apusenii Sălajului. In Valcău de Jos there lived the largest Hungarian community in the Apusenii Sălajului, which from 1956 to 1977 lost $38.04 \%$ of the actual. At the same time, in addition to diminishing the Hungarian community, the demographic decline in this spread was also caused by a decrease in the Romanians ' population by $4.87 \%$.

In the period 1977-1992, the demographics in the Apusenii Sălajului have seen considerable decreases, ethnic structures in administrative units having to face major dysfunctions. In the case of Cizer, the Romanian demographic component lost $30.70 \%$ of the actual, and the most destructed Romanian community was in the village of Pria, where Romanians fell by $47.10 \%$. The migration of the population in Plopiss coincided with the recording of a decrease of $16.36 \%$ in the Slovak community and Romanians by $20.53 \%$. The most depopulated Romanian community in the Plopiş administrative unit was registered at the Iaz village level, with a decrease of $47.92 \%$. Similar case was recorded in the Sâg, where the Romanian population decreased by $23.03 \%$ and the Slovak community lost $6.61 \%$ of the actual. The most depopulated village in the commune of Sâg, was Mal, losing from 1977-1992, 32.08\% of Romanian citizens. The high rate of population decline in Halmăşd was primarily due to the decrease of ethnic Romanians by $15.58 \%$, and secondly by the numerical decrease of the Gypsy by 38.31\%. The largest Gypsy community was in the village of Cerişa, which also recorded the greatest loss of $88.57 \%$ at the level of the administrative unit. In Valcău de Jos, the Hungarian community and Romanian contributed to doubling the percentage of population decline at administrative level, compared to the 1956-1977. At the communal level, the Romanian community depopulated by $10.84 \%$ and the Hungarian by $26.90 \%$. The Hungarians were positioned in the Valcău de Jos, the community destructing by $28.82 \%$.

After the end of the ethatism in the year 1989, in the geographical space of the Apusenii Sălajului, two cases were recorded in which the demographic decline diminished from the period 1977-1992. In both the Cizer and the Sâg, this decrease was due to the proliferation of the ethnic Gypsy. If, in the 1956 census, no person of Gypsy ethnicity was recorded in the Cizer, the census in the year 2011 , there was a gypsy community consisting of 252 people. The most fulminant evolution of ethnic Gypsy was recorded in the territory of the Sâg, where 679 
people were reviewed at the census in the year 2011, increasing from 1992 with $84.01 \%$. We have found that, from the first demographic census following the decree prohibiting abortion and until the second census of the $21^{\text {st }}$ century, the gypsy ethnicity had the most rapid pace of prosperity in the Apusenii Sălajului, continuously increasing its flocks in each administrative unit. The Valcău de Jos faced the most acute demographic decline, reaching from 9.18\% in 1992, to $20.78 \%$ in 2011 , due to a decrease in the Romanian population by $30.30 \%$ and Hungarians by $34.40 \%$ respectively. However, if the two ethnicities recorded significant losses, the Gypsy ethnicity had an excessive increase of $108.45 \%$ (table 2).

Table 2. Numerical evolution of ethnics in Apusenii Sălajului

(Source: own processing after population census of 21 February 1956: Population demographic Structure: number and territorial distribution of population, marital status, nationality, mother tongue, training level, families, Central Directorate of Statistics, Bucharest, 1961; Population and Housing census of 5 January 1977, Directorate-General for Statistics, Bucharest, 1980; Population census and inhabitants of 7 January 1992: Sălaj County: General results, County Department of Statistics Sălaj,

Zalău, 1994; Population and Housing Census of 2011, National Institute of Statistics, Bucharest)

\begin{tabular}{|c|c|c|c|c|c|c|c|}
\hline Ethnicities & 1956 & 1977 & $\%$ & 1992 & $\%$ & 2011 & $\%$ \\
\hline Romanians & 19.487 & 17.449 & $-10,45$ & 13.810 & $-20,85$ & 9.918 & $-28,18$ \\
\hline Slovaks & 1.559 & 1.395 & $-10,51$ & 1.180 & $-15,41$ & 898 & $-23,89$ \\
\hline Gypsies & 30 & 456 & 1.420 & 880 & 92,98 & 1.870 & 112,5 \\
\hline Hungarians & 297 & 184 & $-38,04$ & 139 & $-24,45$ & 89 & $-35,97$ \\
\hline
\end{tabular}

The Romanian ethnic element had a broader demographic base, with a more vigorous biological character, and the majority in the ethnic structure at regional level (Apusenii Sălajului) and at local level (administrative-territorial unit) (Edroiu and Pușcaș, 1995, p. 21). We note from table 3 that local ethnic structures in the 1956 census were dominated by Romanians, except for the Plopiss where Slovaks were still in high numbers. The most representative Romanian habitat was Cizer, where there was a bi-ethnic structure consisting of Romanians and Hungarians, the latter having a flock of only four people. Looking comparatively, table 3 highlights the continuity of the Romanian element in the Apusenii Sălajului, but with increasing protuberances of the Gypsy communities. It is the only ethnicity in the Apusenii Sălajului that prospered throughout the period studied, increasing its regional population from 30 people to the census of 1956, to 1.870 individuals at the census in 2011 (an excessive percentage increase of $6.133 \%$ ).

The Romanian population of the Apusenii Sălajului fell by $49.10 \%$ from 1956 to 2011, as proof of the action of the regime to disintegrate the rural area. By more or less legal measures, the population had to migrate to other administrative units, others left the country. Even though the rural area was not destroyed as the communist regime wanted, after its end in 1989, Romanians continued to migrate due to lack of jobs and low levels of life.

Since the years 1960 of the $20^{\text {th }}$ century, a part of the Slovak population positioned in the geographical areas of the Apusenii Sălajului began to migrate to the region of Arad (Banat). These migratory processes were based on economic reasons, with Slovaks repositioning themselves in the geographic space of some administrative units where the Slovak element was already much better strengthened, Butin, Vucova and Nădlac (Štefanko, 2004, p. 19). After the establishment of communism, mountainous settlements in the Apusenii Sălajului 
did not enter the sphere of influence of collectivization, being kept private household. However, the collectivization blanket did not escape the farmland from the fields of hydrographic courses, resulting in a decrease in the life level of the anthropogenic component. The corroboration of agricultural land collectivization actions with the opening up of some enterprises for the male workforce led to the closing of a binary management system in Slovak villages. Thus, women were dealing with cattle growth and the work of the land, and men were trained in the activities of factories. The industrialisation of urban centres and the loss of jobs in settlements inhabited by Slovaks, coincided with a new phase of demographic migration. The Slovak rural exodus was carried out in two directions. Some of them migrated and settled in the industrial centres in the immediate proximity to the Aleșd, Voivozi, Oradea, and another party migrated to agrarian localities such as Aștileu, Urvind, Tileagd (Štefanko, 2004, p. 23). The beginnings of democracy have led to the systematic reduction of jobs in businesses, and the only way to survival of the Slovaks in the Apusenii Sălajului remained the work of the land. Subsistence farming caused by the precarity of the edaphic coating has boosted the emigration of the young population to other regions of the country or abroad. The migration of young people has resulted in a considerable increase in the average age among the Slovak population, thus becoming acute the viability of the school institutions with the Slovak language from Apusenii Sălajului (Štefanko, 2004, p. 79).

Table 3. Ethnic evolution of the population of the Apusenii Sălajului at the local level (Source: own processing after population census of 21 February 1956: Population demographic Structure: number and territorial distribution of population, marital status, nationality, mother tongue, training level, families, Central Directorate of Statistics, Bucharest, 1961; Population and Housing Census of 2011, National Institute of Statistics, Bucharest)

\begin{tabular}{|c|c|c|c|c|c|}
\hline & Years/Percentage & Romanians & Hungarians & Gypsies & Slovaks \\
\hline & 1956 & 4214 & 4 & 0 & 0 \\
\hline & 2011 & 1905 & 0 & 252 & 0 \\
\hline Halmășd & $\%$ & -54.79 & -100.00 & $*$ & 0 \\
\hline & 1956 & 3707 & 3 & 28 & 132 \\
\hline & 2011 & 1904 & 7 & 361 & 30 \\
\hline Plopiș & 1956 & -48.64 & 133.33 & 1189.29 & -77.27 \\
\hline & 2011 & 2754 & 6 & 1 & 1314 \\
\hline & $\%$ & 1417 & 0 & 159 & 770 \\
\hline Sâg & 1956 & -48.55 & -100.00 & $* *$ & -41.40 \\
\hline & 2011 & 4953 & 8 & 1 & 113 \\
\hline & $\%$ & 2411 & 0 & 679 & 98 \\
\hline Valcău de Jos & 1956 & -51.32 & -100.00 & $* *$ & -13.27 \\
\hline & 2011 & 3859 & 276 & 0 & 0 \\
\hline & $\%$ & -40.89 & -70.29 & $*$ & 0 \\
\hline
\end{tabular}

*- we can't calculate the percentage

**- percentage increase is very high 
The socialist authorities set up a programme in the year 1977, attempting to extend control of the Gypsy minority. This program was never made public, and its implementation was done locally, so the police could constrain the Gypsy who practiced their traditional trades to return to the factories of the country. However, some of the Gypsy took advantage of the weaknesses of the system, providing goods that only they were able to ensure (Pons, 1999, p. 35). The continuing ascent of the Gypsy population from the Apusenii Sălajului, was due to the social aid system which specifically targeted families with a precarious material situation. A number of medical services were offered free of charge, and pro-natalist policy led to a decrease in mortality among women of Gypsy ethnicity (Pons, 1999, p. 39). The significant increase in the Gypsy community from the Apusenii Sălajului from 1956 to 1977, can be put on account of ambiguities during the year 1956 census. There is a likelihood that some may have declared belonging to the ethnicity Romanian, and in the 1977 census they really recognized their membership of the Gypsy ethnicity, which led to the demographic explosion in this range. This hypothesis is all the more credible, the socialist censuses were made on the basis of declarations and not on the basis of social surveys, clearly identifying ethnic affiliation (Costachie et al., 2011, p. 143). This probable error is reinforced by the Amza (1996 quoted by Stoenescu, 2015, p. 429) claiming that most of the Gypsy people lived in rural areas in Gypsy villages or hamlet attached to villages where the ethnic Romanian or Hungarian ethnicity, on this occasion many declaring themselves either Romanians or Hungarians. At the demographic census of the year 1977, the Gypsy ethnicity constituted the third minority in the geographical space of the Apusenii Sălajului, following Romanians and Slovaks (Pons, 1999, p. 46). The projects on helping Gypsy communities continued in capitalism, which resulted in their numerical ascent between 1992-2011 and 112.5\% at the level Apusenii Sălajului.

The migration of Hungarians from the Apusenii Sălajului began after the communist regime was established, but an important migratory wave took place in the years 1980 of the 20th century, a demographic phenomenon that was intensely perpetuated and after the end of socialism (Edroiu and Pușcaș, 1995, p. 21). The geographic distribution of the Hungarians from the Apusenii Sălajului was homogenous, with the largest local community being at the Valcău de Jos, which continued its existence throughout the period studied, but with decreasing numerals from a census to another. From 1956 to 1992, local Hungarian communities also existed in the rest of the municipalities, but numerically did not pass 10 people.

\section{Changes in the confessional structure of the administrative-territorial units in Apusenii Sălajului}

The confessional structure is the demographic indicator with the deepest changes caused by the political factor, so at the census during the socialist period, the confession was not recorded (Boțan, 2010, p. 361).

The Greek Catholic cult suffered the most abundant persecutions during the period studied, but especially during communism, established in the year 1948 and lasted until 1989. As mentioned by us Boțan (2010), the demographic censuses during this period did not record the confessions of the inhabitants. In this way, in order to highlight the religious mutations in the Apusenii Sălajului, we took into account the statistical data provided by the census in the year 
1941. This is the last census of the population, before the establishment of the communist regime, a regime that has propagated atheism successively.

In the year 1941, Greek Catholics were the most numerous confessional in the analyzed territory, with a regional flock of 17.762 people. In their wake were Roman Catholics with 4.180 people, and in the third place were Reformations with 261 people. The Orthodox confession had only 38 people in the Apusenii Sălajului, but these hierarchs had a lot to change after the year 1948. The Greek-Catholic cult dominates in four administrative units of privileges except for the Plopiş where they actually higher had Roman Catholics (table 4).

Table 4. Confessional evolution of the population of the Apusenii Sălajului at the local level (Source: own processing after Rotariu et al., 2002; Population and Housing Census of 2011, National Institute of Statistics, Bucharest)

\begin{tabular}{|c|c|c|c|c|c|c|}
\hline & Years /Percentage & Orthodox & $\begin{array}{c}\text { Roman } \\
\text { Catholic }\end{array}$ & $\begin{array}{c}\text { Greek } \\
\text { Catholic }\end{array}$ & Reformed & Pentecostal \\
\hline Cizer & 1941 & 13 & 29 & 4018 & 10 & 0 \\
\hline & 2011 & 2005 & 0 & 64 & 0 & 67 \\
\hline $\begin{array}{c}\text { Halmăș } \\
\text { d }\end{array}$ & 1941 & $* *$ & -100.00 & -98.41 & -100.00 & $*$ \\
\hline & 2011 & 2165 & 32 & 101 & 0 & 0 \\
\hline & $\%$ & $* *$ & -95.30 & -97.04 & -100.00 & $*$ \\
\hline Plopiș & 1941 & 2 & 2908 & 2471 & 8 & 0 \\
\hline & 2011 & 1263 & 771 & 274 & 0 & 28 \\
\hline & $\%$ & $* *$ & -73.49 & -88.91 & -100.00 & $*$ \\
\hline Sâg & 1941 & 8 & 316 & 4440 & 16 & 0 \\
\hline & 2011 & 2417 & 102 & 72 & & 443 \\
\hline & $\%$ & $* *$ & -67.72 & -98.38 & -100.00 & $*$ \\
\hline $\begin{array}{c}\text { Valcău } \\
\text { de Jos }\end{array}$ & 1941 & 7 & 246 & 3424 & 219 & 0 \\
\hline & 2011 & 2379 & 4 & 79 & 69 & 198 \\
\hline & $\%$ & $* *$ & -98.37 & -97.69 & -68.49 & $*$ \\
\hline
\end{tabular}

*- we can't calculate the percentage

**- percentage increase is very high

The Greek Catholic Church was banned by Decree 358/1.XII.1948 (Moisin, 1998, p. 7). Until then, between 1 October and 1 December 1948, over 600 priests of the Greek Catholic cult were arrested because of the refusal to move to the Orthodox confession. Those who hid were caught and convicted, many dying in prisons and labor camps (Moisin, 1998, pp. 4-5). The arrests specifically targeted the Greek Catholic bishops: Ioan Suciu, Alexandru Rusu, Valeriu Traian Frențiu, Ioan Bălan, Tit Liviu Chinezu, Vasile Aftenie and Bishop Cardinal Iuliu Hossu (Moisin, 1998, pp. 5-6). With these devastation of the Greek Catholic cult, the population of this religious cult was constrained to convert to the Orthodox cult. This was achieved in a very large proportion, so that in the 2011 census, the confessional structure in the Apusenii Sălajului 
was dominated by the Orthodox. Compared to the 1941 census, the regional population of the Greek Catholics decreased by $89.84 \%$, and the herd of the orthodox population increased from 38 people to 12.488 people (table 5).

Violence against Greek Catholics took place in the first five years after the fall of communism, but with lower intensity. Thus, the confrontations were contained in a letter of a Greek Catholic believer in the village of Fizes, the commune Sâg (Moisin, 1995, p. 594) in which fierce discussions between Orthodox and Greek Catholic priests are reported, even on a day of great celebration for both denominations. Following these extensive religious mutations, at the first census that followed communism, the Orthodox confession clearly dominates the confessional structure at regional level, but also the confessional structures at local level. Also, in the ranks of the Orthodox confession, a part of the Roman Catholics, whose regional effectively decreased by $71.38 \%$. The Reformed confession lost $60.91 \%$ of the regional community, the followers of this religious cult being ethnic Hungarians, a party prefering to migrate to get rid of repression. However, we must mention that after the end of communism, conditions have been created for the formation of new confessions, which have gathered more and more people. One of the most prolific new cults was the Pentecostal that from 1992 to 2011 rose by $2.017 \%$, attracting believers from Orthodox, Roman Catholic and Greek Catholic confessions.

\section{CONCLUSIONS}

The period studied was one with many demographic changes in the Apusenii Sălajului. Demographic evolution has been continuously dynamic, leading to more or greater numerical decreases from one census to another. The demographic component was continuously dynamic both during the communist period and in the capitalist period. The migration of the population during the socialist period was largely caused by authorities, who wanted to destructuate the rural area. The Apusenii Sălajului are entirely rural space, the communist laws on systematization of the rural environment causing demographic failures. The most important territorial disparities were caused in the confessional structure. The confessional diversity in the Apusenii Sălajului was considerably narrowed in the socialist period. The prohibition of the Roman Church contributed to the migration of ethnicities, or to the conversion of the remaining to the Orthodox cult. If at the time of the establishment of communism, in the Apusenii Sălajului there was a large Greek-Catholic regional community, at the end of the regime this cult almost no longer exists. Moreover, in the local plan, the Greek Catholics dominated the confessional structures in four administrative units, and the Roman Catholics in a territorial unit. The Slovak community of Roman Catholic confession has migrated largely from the Apusenii Sălajului to escape the repercussions. We can say that the ethnic and confessional structure in the Apusenii Sălajului was in close interaction during the period studied, and the action of the communist regime on them led to the emergence of ethnic-confessional disparities.

\section{REFERENCES}

Akturk, S. (2007). Continuity and change in the regimes of ethnicity in Austria, Germany, the USSR/Russia, and Turkey: Varieties of ethnic regimes and hypotheses for change. Nationalities Papers, 35(1), 23-49. doi:10.1080/00905990601124421

Amza, T. (1996). Țiganii, necunoscuții de lângă noi [The Gypsy, the strangers next to us], Editura 
Atlas-Lex, București.

Boțan, C.N. (2010). Țara Moților. Studiu de geografie regională [Land of the Moți. Regional Geography Study], Editura Presa Universitară Clujeană, Cluj-Napoca.

Clark, J. (2002). Frequent Incompatibilities: Ethnic and Religious Diversity and the Nations of the Middle East. Comparative Studies of South Asia, Africa and the Middle East, 22(1), 36-42.

Costachie, S., Dieaconu, D., Soare, I. (2011). Rromii (țiganii) din România, aspecte istorico-demografice și socio-culturale [Roma (Gypsy) in Romania, historical-demographic and socio-cultural aspects], Editura Transversal, Târgoviște.

Darulová, J., Koštialová, K., \& Nováková, K. S. (2018). Cultural and Confessional Specifics of National Minorities of Slovakia as a Part of Identity Examples of Urban and Rural Environment. European Journal of Science and Theology, 14(6), 107-114.

Decree No. 770 of 1 October 1966 retrieved at http://www.legex.ro/Decretul-770-1966-363.aspx.

Deletant, D. (2001). Teroarea comunistă în România, Gheorghiu-Dej și statul polịtienesc, 1948-1965 [Communist terror in Romania, Gheorghiu-Dej and the police state], Editura Polirom, București.

Edroiu, N., Pușcaș, V. (1995). Maghiarii din România [Hungarians in Romania], Fundația Culturală Română, Centrul de Studii Transilvane, Cluj-Napoca.

Ghiță, E. (2011). Population, Ethnicity and Confession in the County of Arad in the Eighteenth Century and Early Nineteenth Century. Eurolimes, (Supp102), 41-55.

Gostyusheva, E.M., Dolzhikov, V.A. (2019). The confessional structure of the population of the Tomsk province according to the first Russian census of 1897. Journal of Tomsk State Uuniversity. History, 59. 12-19.

Gumenai, I. (2008). Religious policy of the Russian Empire as concerns the confessional minorities from Bessarabia in the XIX-th century. Eurolimes, (5), 35-43.

Herman, G.V. (2009). Omul şi modificările antropice din Câmpia Someşului [The man and anthropogenic changes in Somes Plain], Editura Universității din Oradea.

Ilieş, M., Herman, G., Hodor, N., Baias, Ș., \& Ilieș, A. (2020). The Dynamics, Structure and Spatial Distribution of the Religious Choices of the Romanian Ethnic Community in the Post-Socialist Period (1992-2011). Journal for the Study of Religions and Ideologies, 19(57), 163-185.

Kamusella, T. (2004), Upper Silesia 1870-1920: Between region, religion, nation and ethnicity. East European Quarterly, 38(4), 443-462.

Law no. 58/1974 retrieved at https://lege5.ro/Gratuit/he2donrz/legea-nr-58-1974-privindsistematizarea-teritoriului-si-localitatilor-urbane-si-rurale.

Lung, M-S. (2019). Demographic changes in Carpathian Mountain Space: a case study on Apuseni Mountains (Romania), between 1850 and 2011. Boletim Goiano de Geografia, 39, 1-27.

Lung, M-S. (2019). Ethnic-confessional cyclicality and continuity in the Petroșani Depression in the period: 1850-2011. Journal of Geography, Politics and Society, 9(1), 12-22, https://doi.org/10.26881/jpgs.2019.1.02.

Lung, M-S., Mureșan, G-A. (2020). Ethnicity and Religion in the Carpathian Mountain Space: Case Study: Mining Centers in the Banat Mountains. Revista Română de Geografie Politică, 22(1), 27-37. https://doi.org/10.30892/rrgp.221104-334

Macháček, L. (2011). Slovak republic and its Hungarian ethnic minority: Sociological reflections. Slovenská politologická revue, (3), 187-210.

Majo, J. (2015). Symbiosis in Diversity: The Specific Character of Slovakia's Religious Landscape, In: Brunn S. (eds) The Changing World Religion Map. Springer, Dordrecht, https://doi.org/10.1007/978-94-017-9376-6_21.

Matlovič, R., Vlčková, V., \& Matlovičová, K. (2015). Religiosity in Slovakia After the Social Change in 1989. In The Changing World Religion Map (pp. 1031-1045). Springer, Dordrecht. https://doi.org/10.1007/978-94-017-9376-6_53.

Moisin, A. (1995). Mărturiile prigoanei contra Bisericii Române Unite cu Roma, Greco-Catolice, între anii 1990-1995 [Testimonials persecution against the Romanian church united with Rome, Greek Catholic, between the years 1990-1995], POLSIB, Sibiu.

Moisin, A. (1998). Minciuna "trecerii” la ortodoxie a românilor uniți, greco-catolici în anul 1948 [The lie "passage" to the Orthodox of the United, Greek-Catholic Romanians in the year 1948], Făgăraș.

Mukharyamov, N. (2004). Ethnicity and the study of international relations in the post-soviet Russia. Communist and Post-Communist Studies, 37(1), 97-109, https://doi.org/10.1016/j.postcomstud.2003.12.004.

Pons, E. (1999). Tiganii din România, o minoritate în tranzịtie [Romanian Gypsy, a minority in transition], Editura Compania, București.

Quinlan, P. (1977). Clash over Romania: British and American Policies towards Romania: 1938-1947, American-Romanian Academy of Arts and Sciences, Los Angeles.

Romanov, V.1., Butuhanov, A. (2001). Riskoobrazujuscie faktory: harakteristika i vlijanie na riski, in Modelirovanie i analiz bezopasnosti, riska i kacestva v sloznsistemah, NPO Omega, SPb. 
Rotariu, T-I., Semeniuc, M., Mezei, E. (2002). Recensământul din 1941, Transilvania [Census of 1941, Transylvania], Editura Presa Universitară Clujeană, Cluj-Napoca.

Scarpim, F.A. (2014). Family, religiosity and ethnical identity in the practices of transmission of baptismal names in a group of Italian immigrants. Brazilian Journal of Population Studies, 31(1), 135-150, Retrieved from https://www.rebep.org.br/revista/article/view/646.

Shemshurenko, O., Tuhvatullin, A., Zabbarova, L. (2016). The problems of relations of ethnic and muslim confessional identity in modern Tatarstan. Journal of Organizational Culture, Communications and Conflict, 20(3), 101-108.

Simoni, A.T., Dagnino, R.S. (2016). Demographic dynamic of indigenous populations in urban areas: a study case of the city of Altamira, Pará. Brazilian Journal of Population Studies, 33(2), 303326. https://doi.org/10.20947/S0102-30982016a0020.

Štefanko, O. (2004). Despre slovacii din România [About Slovaks in Romania], Editura Vydavatel'stvo Ivan Krasko, Nadlak.

Stoenescu, A.M. (2015). Țiganii din Europa și din România: Studiu imagologic [European and Romanian Gypsy: imagological study], Editura RAO, București.

Surd, V., Zotic, V., Puiu, V., Moldovan, C. (2007). Riscul demografic în Munții Apuseni [Demographical risk in the Apuseni Mountains], Editura Presa Universitară Clujeană, Cluj-Napoca.

Tofan, G-B. (2014). The ethnic and confessional structure of Harghita County in 2011. Analale Universității București. Seria Geografie, 83-92.

Truzzi, O.M.S., Bassanezi, M.S.B. (2013). Population, ethnic groups and the coffee industry: São Carlos, Brazil, 1907. Brazilian Journal of Population Studies, 26(2), 197-218. Retrieved from https://www.rebep.org.br/revista/article/view/134.

Zekanovic, I., Gnjato, R. (2018). Disintegration of the former SFR Yugoslavia and changes in the ethno-confessional structure of some cities of Bosnia and Herzegovina. Regional Economy, 26(4), 685-696, http://dx.doi.org/10.22363/2313-2329-2018-26-4-685-696.

*** (1961). Recensămîntul populației din 21 februarie 1956 : structura demografică a populației : numărul şi repartizarea teritorială a populației, starea civilă, naționalitate, limba maternă, nivel de instruire, familii, Direcția Centrală de Statistică [Population census of 21 February 1956: Population demographic Structure: number and territorial distribution of population, marital status, nationality, mother tongue, training level, families, Central Statistics Directorate], Bucureşti.

*** (1980). Recensámîntul populației şi al locuințelor din 5 ianuarie 1977, Direcția Generală de Statistică [Population and Housing census of 5 January 1977, Directorate-General for Statistics], București.

*** (1994). Recensământul populației și locuitorilor din 7 ianuarie 1992 : județul Sălaj : rezultatele generale, Direcția Județeană de Statistică Sălaj [Population census and inhabitants of 7 January 1992: Sălaj County: General results, County Department of Statistics Sălaj], Zalău.

*** (2011). Recensământul populației şi al locuințtelor din 2011, Institutul Național de Statistică [Population and Housing Census of 2011, National Institute of Statistics], București.

Submitted:

November 24, 2020
Revised:

December 22, 2020
Accepted and published online: January 11, 2021 